\title{
Self-perceived health in dental students: a cross-sectional study
}

\section{Autopercepção de saúde em estudantes de odontologia: um estudo transversal}

\author{
Claudia Lobelli Rangel Gomes ${ }^{1}\left(\mathbb{D}\right.$, Samuel de Carvalho Chaves-Junior ${ }^{2}$ (D), Maria Beatriz Duarte Gavião ${ }^{3}$ (D)
}

1. Department of Pediatric Dentistry, Pedodontics Area, Piracicaba Dental School, University of Campinas, Piracicaba, SP Brazil. 2. PhD Student, Department of Pediatric Dentistry, Pedodontics Area, Piracicaba Dental School, University of Campinas, Piracicaba, SP Brazil. 3. Department of Pediatric Dentistry, Pedodontics Area, Piracicaba Dental School, University of Campinas, Piracicaba, SP Brazil.

\begin{abstract}
Objective: this is a cross-sectional descriptive study, with the objective of verifying the relationship between health self-perception, sociodemographic characteristics, weight status and physical and psychological symptoms in a group of dental students. Methods: one hundred and sixty individuals from a Dental School, aged 16-24 years, participated. Questionnaires were applied for socioeconomic characteristics, psychological symptoms, and self-perception of health. Clinical examinations were performed to evaluate oral health (CPOD index, frequency of brushing and dental consultations) and weight status (Body Mass Index, BMI). The data were analyzed by descriptive statistics, Student t, Mann-Whitney, chi-squared tests and logistic regression. Results: the prevalence of overweight/obese individuals was $29 \%$, with a similar proportion for the sexes $(\mathrm{P}=0.23)$. Weight status, satisfaction with body image, comparison with others, feeling depressed or nervous, and eating habits were factors associated with self-perception of health (OR 0.20-5.19, $\mathrm{P}<0.05)$. Individuals who were satisfied with their body image or considered their eating habits healthy were more likely to perceive health positively $(\mathrm{OR}=4.24$ e $\mathrm{OR}=4.27$ ). Conclusion: socio-demographic characteristics showed no influence on self-perception of health, except weight status that was negatively associated with self-perception of health. Individuals who show satisfaction with their body image and consider themselves to have healthy eating habits perceived their health positively.
\end{abstract}

Keywords: Nutritional Status. Oral Health. Health Behavior. Body Image.

\section{Resumo}

Objetivo: trata-se de um estudo transversal descritivo, com o objetivo de verificar a relação entre autopercepção de saúde, características sociodemográficas status de peso e sintomas físicos e psicológicos em um grupo de estudantes de odontologia. Métodos: participaram 160 indivíduos, entre 16 e 24 anos, de uma faculdade de Odontologia. Os questionários foram aplicados para características socioeconômicas, sintomas psicológicos e autopercepção de saúde. Foram realizados exames clínicos para avaliação da saúde bucal (índice CPOD, frequência de escovação e de consultas odontológicas) e status de peso (Índice de Massa Muscular). Resultados: a prevalência de sobrepeso/obesidade foi de $29 \%$, com proporção semelhante para os sexos (P = 0,23). 0 status do peso, a satisfação com a imagem corporal, a comparação com os outros, a sensação de estar deprimido ou nervoso e os hábitos alimentares foram fatores associados à autopercepção de saúde (OR 0,20-5,19, $\mathrm{P}<0,05)$. Indivíduos satisfeitos com sua imagem corporal ou que consideraram seus hábitos alimentares saudáveis apresentaram maior probabilidade de perceber a saúde positivamente $(\mathrm{OR}=4,24$ e $O \mathrm{R}=4,27)$. Conclusão: as características sociodemográficas não mostraram influência na autopercepção de saúde. Indivíduos que demonstraram satisfação com a imagem corporal e que consideraram ter hábitos alimentares saudáveis perceberam sua saúde positivamente.

Palavras-chave: Estado Nutricional. Saúde Bucal. Comportamento de Saúde. Imagem Corporal.

\section{INTRODUCTION}

Self-perceived health, which is an individual's own beliefs about the state of his/her health, and associated factors are significant public health concerns $\mathrm{s}^{1,2}$, influencing the directions of individual's actions ${ }^{3}$. Self-perceived health constitutes an important measurement whereby the population's health can be evaluated, since it provides an overview of the diverse components of health. Moreover, self-perceived health can be influenced by factors relating to sociodemographic status, body image and satisfaction, emotional aspects, and health behavior ${ }^{1}$.
The health of university students should be considered of importance since universities are dealing with future professionals and policy-makers who will influence others' health and quality of life ${ }^{4,5}$. It is important to identify whether the students are applying their acquired knowledge to beneficial everyday behaviors, as well as how they perceive their own health. Determining the health behavior of healthcare students is important to strengthen their credibility as role models promoting health ${ }^{6,7}$. They are future healthcare professionals and will be able to provide better care for others when they 
engage in self-care and promote the highest level of their own well-being ${ }^{8}$.

In this context, the aim of the present study was to determine whether there is a relationship between self-perceived health, sociodemographic characteristics, weight status, and physical and psychological symptoms in a group of dental students.

\section{METHODS}

This is a descriptive cross-sectional study with a quantitative approach, approved by The Research Ethics Committee of the Piraciaba Dental School, University of Campinas, Protocol no 075/2014.

A convenience sample was selected consisting of adolescents and young adults, aged 16-24 years old. The sample-size calculation was estimated in 161 individuals, taking into account the study of $\mathrm{PikO}^{1}$, in which $18.1 \%$ of participants presented negative self-perceived health, a maximum tolerable error of $5 \%$ and a confidence level of $90 \%$. About 300 individuals at the Dental School were directly contacted by the researcher and asked to participate. Of those, 194 were accepted and examined. However, 14 volunteers dropped out, citing lack of time or interest in completing the questionnaire, 20 volunteers were excluded because they were not undergraduates and graduate students, resulting in a final sample of 160 subjects.

The parents/guardians of volunteers under 18 years old and the volunteers who agreed to participate signed the Informed Consent. Those under 18 years old signed the Informed Assent. The inclusion criteria were healthy individuals, i.e., with good systemic (self-declared) and oral conditions (by clinical examination) and able to participate in the research. The exclusion criteria were oral deformities, dental anomalies, current orthodontic treatment, and fixed or removable oral prosthesis).

The socio-demographic variables were: gender, age, selfdeclared skin color, family income, and parents' education level. Moreover, weight status was evaluated.

Oral conditions were assessed using the DMFT index (sum of the numbers of permanent, decayed, missing, and filled teeth), according to World Health Organization (WHO) criteria9, by an examiner trained and calibrated (C.L.R.G.) during a pilot study (substantial intra- and inter-agreement, Kappa $=0.80$ ). Moreover, the participants replied about the frequency of toothbrushing. The research was conducted at the Piracicaba Dental School, University of Campinas, Piracicaba, SP, Brazil, from March to August 2015.

Weight status was determined based on Body Mass Index (BMI $=$ weight $/$ height 2$)^{2}$. Weight $(\mathrm{Kg})$ was obtained with an analog scale, and height $(\mathrm{m})$ by means of a stadiometer (Welmy type 110). The BMI interpretation for volunteers aged equal or more than 20 years was based on weight status categories:
Underweight (Below 18.5); Normal or Healthy Weight (18.5 24.9); Overweight (25.0 - 29.9); Obese (30.0 and above). For those aged 15-19 years the interpretation was according to the CDC BMI-for-age growth charts, which visually show BMI as a percentile ranking, taking into account age and sex. The weight status categories are: Underweight (Less than the 5th percentile); Normal or Healthy Weight (5th percentile to less than the 85th percentile); Overweight (85th to less than the 95th percentile); Obese (95th percentile or greater) ${ }^{9}$.

Assessment of health perception was carried out based on nine questions from the Health Behavior in School Children (HBSC) 10 developed by WHO to study lifestyle in adolescents, adapted for Portuguese language (personal communication). The questions were self-applied and related to self-perceived health, eating habits, satisfaction with body image, emotional symptoms, and oral health behavior (frequency of tootbrushing).

\section{Statistics}

Descriptive statistics consisted of frequencies, means, and standard deviations. Weight status was grouped into underweight/normal weight and overweight/obese groups. Student t-test for independent samples or the Mann-Whitney test, according to the normality test (Kolmogorov-Smirnov), or the chi-squared test was applied when indicated. To verify the variables related to the self-perception of health, simple- and multiple-logistic regressions were applied. The question "How healthy do you feel you are?" was used as a dependent variable. The respective answer scale contained four alternatives, categorized, for the regressions to be performed, into "very healthy/healthy" (0) and "somewhat unhealthy/ very unhealthy" (1). The independent variables were also dichotomized according to the positive and negative aspects of the answers. First, simple logistic regression was carried out with the socio-demographic data, weight status, and the questions from the HBSC. After that, two models were built for multiple analysis, with health perception the dependent variable in both. Socio-demographic data, and weight status were the independent variables for the first model, and the questions from the HBSC were the independent variables for the second model. The variables with a $\mathrm{P}<0.25$ in the simple logistic regression were included in the multiple models. Those with $\mathrm{P}<0.05$ were considered as explicative variables in the multiple models. The SPSS (20.0 SPSS Inc., Chicago, IL, USA) was used.

\section{RESULTS}

The volunteers were dental students $(n=140)$ and postgraduate students $(n=20)$. Table 1 shows the volunteer' sociodemographic characteristics. The prevalence of females (69\%) was higher than that of males (31\%). The average age was $20.98 \pm 1.80$ years. Most of the parents had a high education level. Family income ranged from three to 30 minimum salaries per month (7.93 \pm 4.62$)$. One minimum salary at the time of the research was about US\$274. The majority of individuals 
reported themselves as 'white'. The prevalence of overweight/ obese individuals was $28 \%$, with similar proportions of the sexes $(p=0.23)$. The DMFT average was $2.59 \pm 1.49$. The frequency of tooth brushing was 3 times per day for the majority of individuals, as expected.

Table 1. Descriptive statistics: socio-demographic, weight status and clinical characteristics according to gender and total sample

\begin{tabular}{|c|c|c|c|c|}
\hline Variables & Characteristics & Female [n (\%)] & Male[n (\%)] & Total [n (\%)] \\
\hline \multirow{4}{*}{ Age (years) } & $16-19$ years & $29(18 \%)$ & $5(3 \%)$ & 34 (21\%) \\
\hline & $20-24$ years & $82(51 \%)$ & $44(28 \%)$ & $126(79 \%)$ \\
\hline & Mean \pm SD & $20.82 \pm 1.88$ & $21.35 \pm 1.56$ & $20.98 \pm 1.80$ \\
\hline & Range (years) & $16-24$ & $17-24$ & $16-24$ \\
\hline \multirow{5}{*}{ Skin color [n (\%)] } & White & $94(59 \%)$ & $39(24 \%)$ & $133(83 \%)$ \\
\hline & Brown & $7(4 \%)$ & $7(4 \%)$ & $14(9 \%)$ \\
\hline & Yellow (East Asian) & $4(3 \%)$ & $3(2 \%)$ & $7(4 \%)$ \\
\hline & Black & $4(3 \%)$ & - & $4(3 \%)$ \\
\hline & No response & $2(1 \%)$ & - & $2(1 \%)$ \\
\hline \multirow{4}{*}{ Mother's level of education [n (\%)] } & $\begin{array}{l}\text { No formal } \\
\text { education }\end{array}$ & - & - & \\
\hline & Grade school & $9(6 \%)$ & $8(5 \%)$ & 17 (11\%) \\
\hline & High school & $29(18 \%)$ & $12(8 \%)$ & $41(26 \%)$ \\
\hline & University & $73(46 \%)$ & $29(18 \%)$ & $102(64 \%)$ \\
\hline \multirow{4}{*}{ Father's level of education [n (\%)] } & $\begin{array}{l}\text { No formal } \\
\text { education }\end{array}$ & $1(1 \%)$ & - & $1(1 \%)$ \\
\hline & Grade school & $9(6 \%)$ & $5(3 \%)$ & $14(9 \%)$ \\
\hline & High school & $32(20 \%)$ & $11(7 \%)$ & $43(27 \%)$ \\
\hline & University & $69(43 \%)$ & $33(21 \%)$ & $102(64 \%)$ \\
\hline \multirow{5}{*}{$\begin{array}{l}\text { Family income (minimum salary per } \\
\text { month*) } \\
{[\mathrm{n}(\%)]}\end{array}$} & Up to 3 & $9(6 \%)$ & $6(4 \%)$ & $11(9 \%)$ \\
\hline & From 4 to 10 & $74(46 \%)$ & $36(23 \%)$ & 110 (69\%) \\
\hline & From 11 to 30 & $19(12 \%)$ & $5(3 \%)$ & $24(15 \%)$ \\
\hline & Did not respond & $9(6 \%)$ & $2(1 \%)$ & $11(7 \%)$ \\
\hline & Mean & & $8.10 \pm 4.24$ & $7.66 \pm 5.39$ \\
\hline Weight $(\mathrm{kg}) \pm \mathrm{SD}$ & Range: 43-109 & $61.04 \pm 10.32$ & $75.99 \pm 13.48$ & $65.62 \pm 13.28$ \\
\hline Height $(m) \pm S D$ & Range: $1.52-1.92$ & $1.64 \pm 0.06$ & $1.77 \pm 0.07$ & $1.68 \pm 0.09$ \\
\hline $\mathrm{BMI} \pm \mathrm{SD}$ (weight/height2) & Range: $15.80-36.32$ & $22.70 \pm 3.63$ & $24.20 \pm 3.82$ & $23.16 \pm 3.74$ \\
\hline \multirow{2}{*}{ Weight status } & $\begin{array}{l}\text { Underweight/ } \\
\text { Normal [n (\%)] }\end{array}$ & 85 (53\%) & $29(18 \%)$ & $114(71 \%)$ \\
\hline & $\begin{array}{l}\text { Overweight/ } \\
\text { Obesity [n (\%)] }\end{array}$ & $26(16 \%)$ & $20(13 \%)$ & 46 (29\%) \\
\hline $\mathrm{DMFT} \pm \mathrm{SD}$ & Range: 0-8 & $2.65 \pm 1.55$ & $2.47 \pm 1.36$ & $2.59 \pm 1.49$ \\
\hline \multirow{3}{*}{ Frequency of toothbrushing } & $3 x$ per day or more & $102(64 \%)$ & $35(22 \%)$ & $137(86 \%)$ \\
\hline & $2 x$ per day & $9(6 \%)$ & $12(8 \%)$ & $21(13 \%)$ \\
\hline & $1 x$ per day & - & $2(1 \%)$ & 2 (1\%) \\
\hline
\end{tabular}

SD (standard deviation), $\quad$ BMI (body mass index), DMFT (decayed, missed, filled, teeth)

*The minimum salary in Brazil in 2015 was R\$ 788.00, corresponding to US\$ 274

Table 2 shows the sample distribution according to the questionnaire responses. Sixty-one percent of the individuals considered themselves very or somewhat healthy. This variable was taken into account for verification of the factors associated with the self-perception of health.
Univariate logistic regression analysis (Table 3) showed that weight status, satisfaction with body image, comparison with others, to feel depressed or nervous, and eating habits were factors associated with self-perceived health (OR 0.20-5.19, $\mathrm{P}<$ $0.05)$. Feeling angry, experiencing difficulty sleeping and DMFT entered in the final model due to $P$ values less than 0.25 . 
Table 2. Selected questions based on the instrument "Health Behavior in Schoolchildren"

\begin{tabular}{|c|c|c|c|}
\hline Questions & $\begin{array}{r}\text { Females } \\
n(\%)\end{array}$ & $\begin{array}{r}\text { Males } \\
\text { n (\%) }\end{array}$ & $\begin{array}{l}\text { Total } \\
\text { n (\%) }\end{array}$ \\
\hline \multicolumn{4}{|l|}{ How healthy do you feel you are? } \\
\hline Very healthy & $6(4 \%)$ & $5(3 \%)$ & $11(7 \%)$ \\
\hline Somewhat healthy & $58(36 \%)$ & $29(18 \%)$ & $87(54 \%)$ \\
\hline Somewhat unhealthy & $45(28 \%)$ & $15(9 \%)$ & $60(38 \%)$ \\
\hline Very unhealthy & $2(1 \%)$ & - & $2(1 \%)$ \\
\hline \multicolumn{4}{|l|}{ What do you think contributes to good health? } \\
\hline It's solely based on luck & - & - & - \\
\hline It is based partly on luck and partly on what I do for myself & $25(14 \%)$ & $18(11 \%)$ & $43(27 \%)$ \\
\hline It is based partly on what I do for myself and partly on luck & $15(9 \%)$ & $8(5 \%)$ & $23(14 \%)$ \\
\hline It depends solely on what I do for myself and how I act & $71(44 \%)$ & $23(14 \%)$ & $94(49 \%)$ \\
\hline \multicolumn{4}{|l|}{ How satisfied are you with your body? } \\
\hline Very satisfied & $6(4 \%)$ & $3(2 \%)$ & $9(6 \%)$ \\
\hline Somewhat satisfied & $24(15 \%)$ & $17(11 \%)$ & $41(26 \%)$ \\
\hline More or less satisfied & $57(36 \%)$ & $23(14 \%)$ & $80(50 \%)$ \\
\hline Somewhat unsatisfied & $20(13 \%)$ & $5(3 \%)$ & $25(16 \%)$ \\
\hline Very unsatisfied & $4(3 \%)$ & $1(1 \%)$ & $5(3 \%)$ \\
\hline \multicolumn{4}{|c|}{ How do you compare your own weight with that of others of your same age? } \\
\hline Very overweight & $1(1 \%)$ & - & $1(1 \%)$ \\
\hline Slightly overweight & $22(14 \%)$ & $7(4 \%)$ & $29(18 \%)$ \\
\hline About the right weight & $55(34 \%)$ & $26(16 \%)$ & $81(51 \%)$ \\
\hline Slightly underweight & $27(17 \%)$ & $16(10 \%)$ & $43(27 \%)$ \\
\hline Very underweight & $6(4 \%)$ & - & $6(4 \%)$ \\
\hline \multicolumn{4}{|c|}{ How do you compare your eating habits with those of others of your same age? } \\
\hline Lots healthier & $14(9 \%)$ & $13(8 \%)$ & $27(17 \%)$ \\
\hline Somewhat healthier & $37(23 \%)$ & $13(8 \%)$ & $50(31 \%)$ \\
\hline Equal & $35(22 \%)$ & $15(9 \%)$ & $50(31 \%)$ \\
\hline Somewhat unhealthier & $22(14 \%)$ & $8(5 \%)$ & $30(19 \%)$ \\
\hline Lots unhealthier & $3(2 \%)$ & - & $3(2 \%)$ \\
\hline \multicolumn{4}{|l|}{ How frequently do you feel depressed? } \\
\hline Almost every day & $6(4 \%)$ & $1(1 \%)$ & $7(4 \%)$ \\
\hline More than once a week & $17(11 \%)$ & $5(3 \%)$ & $22(14 \%)$ \\
\hline About once a week & $10(6 \%)$ & $4(3 \%)$ & $14(9 \%)$ \\
\hline About once a month & $34(21 \%)$ & $11(7 \%)$ & $45(28 \%)$ \\
\hline Almost never or never & $44(28 \%)$ & $28(18 \%)$ & $72(45 \%)$ \\
\hline \multicolumn{4}{|l|}{ How frequently do you feel nervous? } \\
\hline Almost every day & $11(7 \%)$ & - & $11(7 \%)$ \\
\hline More than once a week & $28(18 \%)$ & $7(4 \%)$ & $35(22 \%)$ \\
\hline About once a week & $28(18 \%)$ & $11(7 \%)$ & $39(24 \%)$ \\
\hline About once a month & $28(18 \%)$ & $16(10 \%)$ & $44(28 \%)$ \\
\hline Almost never or never & $16(10 \%)$ & $15(9 \%)$ & $31(19 \%)$ \\
\hline
\end{tabular}




\begin{tabular}{|c|c|c|c|}
\hline Questions & $\begin{array}{r}\text { Females } \\
\mathrm{n}(\%)\end{array}$ & $\begin{array}{r}\text { Males } \\
\text { n (\%) }\end{array}$ & $\begin{array}{l}\text { Total } \\
\text { n (\%) }\end{array}$ \\
\hline \multicolumn{4}{|c|}{ How frequently do you feel angry? } \\
\hline Almost every day & $9(6 \%)$ & $1(1 \%)$ & $10(6 \%)$ \\
\hline More than once a week & $24(15 \%)$ & $6(4 \%)$ & $30(19 \%)$ \\
\hline About once a week & $29(18 \%)$ & $17(11 \%)$ & $46(29 \%)$ \\
\hline About once a month & $31(19 \%)$ & $11(7 \%)$ & $42(26 \%)$ \\
\hline Almost never or never & $18(11 \%)$ & $14(9 \%)$ & $32(20 \%)$ \\
\hline \multicolumn{4}{|c|}{ How frequently do you experience difficulty sleeping? } \\
\hline Almost every day & $7(4 \%)$ & $1(1 \%)$ & $8(5 \%)$ \\
\hline More than once a week & $9(6 \%)$ & $9(6 \%)$ & $18(11 \%)$ \\
\hline About once a week & $16(10 \%)$ & $2(1 \%)$ & $18(11 \%)$ \\
\hline About once a month & $16(10 \%)$ & $5(3 \%)$ & $21(13 \%)$ \\
\hline Almost never or never & $63(39 \%)$ & $32(20 \%)$ & 95 (59\%) \\
\hline
\end{tabular}

Table 3. Simple logistic regression according to health perception as a dependent variable

Dependent variable: health perception. Independent variables: socio-demographic variables, DMFT, nutritional status, and questions (HBSC)

\begin{tabular}{|c|c|c|c|c|}
\hline & Coefficient & p-value* & OR & IC $95 \%$ \\
\hline Gender & 0.51 & 0.16 & 1.66 & $0.81-3.40$ \\
\hline Age & -0.44 & 0.26 & 0.65 & $0.30-1.39$ \\
\hline Skin color & 0.10 & 0.81 & 1.11 & $0.48-2.57$ \\
\hline Mother's level of education & 0.05 & 0.87 & 1.06 & $0.54-2.05$ \\
\hline Father's level of education & -0.62 & 0.06 & 0.53 & $0.28-1.04$ \\
\hline Family income & 0.27 & 0.43 & 1.31 & $0.67-2.54$ \\
\hline Weight status & 0.78 & 0.03 & 2.18 & $1.09-4.38$ \\
\hline DMFT & 0.50 & 0.12 & 1.65 & $0.87-3.10$ \\
\hline Contribution to good health & 0.17 & 0.60 & 1.19 & $0.62-2.27$ \\
\hline Satisfaction with the body & 1.44 & 0.0005 & 4.23 & $1.88-9.55$ \\
\hline Comparing the own weight with that of others of the same age & -1.62 & 0.0002 & 0.20 & $0.08-0.47$ \\
\hline Comparing eating habits with those of others of the same age & 1.64 & 0.0001 & 5.19 & $2.26-11.93$ \\
\hline Feel depressed & -0.96 & 0.008 & 0.38 & $0.19-0.78$ \\
\hline Feel nervous & -0.76 & 0.02 & 0.46 & $0.24-0.90$ \\
\hline Feel angry & -0.72 & 0.03 & 0.49 & $0.25-0.94$ \\
\hline Difficulty sleeping & -0.77 & 0.03 & 0.46 & $0.23-0.94$ \\
\hline
\end{tabular}

The final model of the multiple logistic regression are in Table 4. The variables that remain with $P$ values lesser than 0.05 showed that individuals satisfied with their body image or considering their eating habits as healthy had a higher probability of having positive perceived health $(O R=4.24$ and $O R=4.27$, respectively). The other variables cited above, which entered in the final model, were not associated with self-perceived health (Table 4). 
Table 4. Multiple logistic regression models according to health perception as dependent variable (only variables with $\mathrm{P}$ values less than 0.25 in simple logistic regression were included)

Dependent variable: health perception. Independent variables: socio-demographic variables, DMFT nd HBSC questions Model chi-square - 48.60; $P<0.0001$

\begin{tabular}{|c|c|c|c|c|}
\hline & Coefficient & p-value* & OR & IC 95\% \\
\hline Gender & 0.24 & 0.57 & 1.28 & $0.54-3.07$ \\
\hline Father's level of education & -0.65 & 0.11 & 0.52 & $0.23-1.15$ \\
\hline Weight status & 0.72 & 0.13 & 2.06 & $0.81-5.28$ \\
\hline DMFT & 0.40 & 0.26 & 1.50 & $0.74-3.05$ \\
\hline Satisfaction with the body & 1.44 & 0.007 & 4.24 & $1.48-12.16$ \\
\hline Comparing the own weight with that of others of the same age & -0.43 & 0.37 & 0.65 & $0.25-1.70$ \\
\hline Comparing eating habits with those of others of the same age & 1.45 & 0.003 & 4.27 & 1.61-11.34 \\
\hline Feel depressed & 0.86 & 0.06 & 2.35 & 0.97-5.72 \\
\hline Feel angry & -0.86 & 0.27 & 0.42 & $0.10-1.71$ \\
\hline Feel nervous & 0.92 & 0.21 & 2.50 & $0.59-10.67$ \\
\hline Difficulty sleeping & 0.11 & 0.80 & 1.11 & $0.48-2.57$ \\
\hline
\end{tabular}

In bold: variables that remained significant in the multiple model

\section{DISCUSSION}

This study evaluated the factors implicated in self-perceived health in adolescents and young adults studying at a dental school. The females represented $69 \%$ of the sample, an expected value, since the Piracicaba Dental School has a greater number of female students ${ }^{11}$, following the trend in relation to the feminization occurrence in the dental courses ${ }^{12}$, as well as in other health areas in Brazil ${ }^{13}$. Most of the participants presented a good socioeconomic level, since $84 \%$ declared family income from four to 30 minimum salaries, meaning middle and upper classes ${ }^{13}$. In addition, most parents had a higher level of education, supporting the socioeconomic level of the sample studied.

The majority of volunteers were of normal weight (64\%), corroborating previous studies ${ }^{14,15}$. The frequency of overweight obesity was $29 \%$ that can be considered high and above the value observed in by Justo et $\mathrm{al}^{14}$, probably due to age, since those authors evaluated only 18 -year-old individuals; it is known that increasing age increases the prevalence of obesity ${ }^{16,17}$. The findings about of overweight/obesity must/be considered disturbing, particularly because the individuals are studying healthcare. Considering that risk factors for dental caries and obesity are common, such as the excess and frequency of carbohydrate consumption, education aiming obesity control should be combined in the dental curriculum with the acquisition of knowledge about the maintenance of good oral health, since obesity is a risk factor for several physical and psychological disorders ${ }^{18,19,20}$.

Good oral conditions were observed, as expected in a sample of dental students. The average DMFT was $2.59 \pm 1.49$ and tooth brushing at least three times daily was highly reported. In addition, most of the sample was composed of students with a good socioeconomic background, supported by the high level of parents' education that could contribute to good oral health. More than half of the participants had positive self-perceived health and were aware that good health depends on their own choices and behavior, agreeing with Moreira et $\mathrm{a}^{3}$. This finding may be attributed to the fact that this population has higher expectations regarding what it means to be in good health, and because this segment would present with a lower incidence of diseases, as previously observed ${ }^{21}$. In addition, age and father's level of education were not related to self-perceived health, which could be attributed to the sample characteristics, i.e., being dental school students and having a level of education similar to that of the parent.

More than half of the study population expressed dissatisfaction with their bodies. Nevertheless, to be of weight equal to or less than others did no influence the self-perceived health, as previously found by Sand, Furberg, Lian et al..$^{22}$. This degree of concern can be confirmed by the fact that the number of adolescents dissatisfied with body image was greater than that of those outside of the normal range.

Most of the volunteers (79\%) reported healthy eating habits. A positive self-perception about eating habits can be a reflection of a well-educated population aware of the benefits of healthy eating for achieving good health. Such benefits were confirmed by the four times greater probability of having a positive selfperception of health reported by those who considered their eating habits healthy. A recent review of the literature showed that lower food expenditure contributes to less-healthy food choices in groups from low socioeconomic levels ${ }^{23}$. Previously, Giskes et al..$^{24}$ showed higher total fat intakes among socioeconomically disadvantaged groups. 
The prevalence of volunteers feeling depressed, nervous, or angry was high, but not associated with self-perceived health, independently of the frequency. These results were unexpected, since self-perceived health can be viewed as a psychosocial health indicator ${ }^{1,25}$. The nature of the questions may have contributed to the lack of association. Considering the high prevalence of psychological symptoms found, efforts toward detecting students' emotional disabilities and helping their well-being would be beneficial, since schools are a key setting for improving adolescent health ${ }^{26}$. Furthermore, while $40 \%$ of the volunteers had difficulty sleeping once a week or more, it did not influence their self-perceived health. Those findings contrasted with Štefan et al. ${ }^{27}$, who verified significant associations between sleep duration and sleep quality with poor self-rated health; moreover, they found that participants with higher psychological distress rated also the perceived health as poor. Maybe, such contradictory findings could be due to different methodological approaches and geographical settings ${ }^{27}$, summed to the different categorization of the variables.

Some study limitations should be pointed out: the crosssectional characteristics of the study do not allow us to establish the direction of the causal relationships. The non-response rate was high, despite our best efforts to invite the students.
Additionally, since the questionnaire was self-applied, overor underreporting of the answers may have occurred, adding a cross-sectional characteristic of the study. Moreover, many volunteers did not know the family income, so a subjective evaluation of socioeconomic status could be used, asking how they rated their family's socioeconomic status1. Finally, the students were from a dental school, indicating the need for a more representative sample from other universities in other regions of Brazil.

\section{CONCLUSION}

In conclusion, in the sample studied, socio-demographic characteristics showed no influence on self-perception of health, except weight status that was negatively associated with self-perception of health. Individuals who demonstrate satisfaction with their body image and consider themselves to have healthy eating habits perceived their health positively.

\section{ACKNOWLEDGEMENTS}

This study was financed in part by the Coordenação de Aperfeiçoamento de Pessoal de Nível Superior - Brasil (CAPES) - Finance Code 001.

\section{REFERENCES}

1. Piko BF. Self-perceived health among adolescents: the role of gender and psychosocial factors. Eur J Pediatr. $2007 \mathrm{Jul}$; 166(7):701-8. PubMed PMID: 17120041. doi: 10.1007/s00431-006-0311-0.

2. World Health Organization. Preventing chronic diseases: a vital investment [Internet]. Geneva: WHO; 2005 [Cited 2019 Jun 20]. Available from: https:// www.who.int/chp/chronic_disease_report/en/.

3. Moreira TM, Santiago JC, Alencar GP. Self-perceived health and clinica characteristics in young adult students from the Brazilian northeast. Rev EsC Enferm USP. 2014 Oct; 48(5):794-803. doi: https://doi.org/10.1590/S0080 6234201400005000004 .

4. Barrieshi-Nusair K, Alomari Q, Said K. Dental health attitudes and behaviour among dental students in Jordan. Community Dent Health. 2006 Sep; 23(3):14751. PubMed PMID: 16995562.

5. Alomari Q, Barrieshi-Nusair K, Said K. Smoking prevalence and its effect on dental health attitudes and behavior among dental students. Med Princ Pract. 2006;15(3):195-9. doi: 10.1159/000092181. PubMed PMID: 16651835

6. Keten HS, Isik O, Guvenc N, Ersoy O, Celik M. Evaluation of the Level of Knowledge of Oral Cancer Among High School Students. J Cancer Educ. 2015 Oct; 32(1): 79-84. doi: http://dx.doi.org/10.1007/s13187-015-0936-7.

7. Tavolacci MP, Delay J, Grigioni S, Déchelotte P, Ladner J. Changes and specificities in health behaviors among healthcare students over an 8-year period. PLoS One. 2018 Mar 22;13(3): e0194188. doi: http://dx.doi. org/10.1371/journal.pone.0194188.

8. Mazurek Melnyk B, Slevin C, Militello L, Hoying J, Teall A, McGovern C. Physical health, lifestyle beliefs and behaviors, and mental health of entering graduate health professional students: Evidence to support screening and early intervention. J Am Assoc Nurse Pract. 2016 Apr; 28(4): 204-11. doi: http:// dx.doi.org/10.1002/2327-6924.12350.
9. World Health Organization. Oral health surveys: basic methods. 5th ed. Geneva: WHO; 2013 [cited 2016 Jan 16]. Available from: http://www.who.int/ oral_health/publications/9789241548649/en/.

10. Wold B. Health behavior in schoolchildren: A WHO cross-national Surrey. Resource Package Questions 1993-94. Norway: University of Bergen; 1995.

11. UNIVERSITY OF CAMPINAS. Statistical Yearbook 2018: Data Base 2017 [Internet]. Campinas: UNICAMP; 2018 [cited 2019 March 11]. Available from: https://www.aeplan.unicamp.br/anuario/2018/anuario2018.pdf.

12. McKay JC, Quiñonez CR. The feminization of dentistry: implications for the profession. J Can Dent Assoc. 2012; 78: c1. Review. PubMed PMID: 22507278.

13. Instituto Brasileiro de Geografia e Estatística. Censo Demográfico IBGE 2010 [Internet]. Rio de Janeiro: IBGE; 2010 [cited 2019 Jun 20]. Available from: https://ww2.ibge.gov.br/home/estatistica/populacao/censo2010/ Brazilian Institute of Geography and Statistics (IBGE).

14. Justo Fde C, Fontanella VR, Feldens CA, Silva AE, Gonçalves H, Assunção $M C$, et al. Association between dental caries and obesity evaluated by air displacement plethysmography in 18-year-old adolescents in Pelotas, Brazil. Community Dent Oral Epidemiol. 2015 Feb; 43(1): 17-23. doi: http://dx.doi. org/10.1111/cdoe.12109.

15. Bucchianeri MM, Eisenberg ME, Neumark-Sztainer D. Weightism, racism, classism, and sexism: shared forms of harassment in adolescents. J Adolesc Health. 2013 Jul; 53(1): 47-53. doi: http://dx.doi.org/10.1016/j. jadohealth.2013.01.006

16. Hulsegge G, Picavet HS, Blokstra A, Nooyens AC, Spijkerman AM, van der Schouw YT, et al. Today's adult generations are less healthy than their predecessors: generation shifts in metabolic risk factors: the Doetinchem Cohort Study. Eur J Prev Cardiol. 2014 Sep; 21(9): 1134-44. doi: http://dx.doi. org/10.1177/2047487313485512. 
17. Malta DC, Stopa SR, Iser BP, Bernal RT, Claro RM, Nardi AC, et al. Risk and protective factors for chronic diseases by telephone survey in capitals of Brazil, Vigitel 2014. Rev Bras Epidemiol. 2015 Dec; 18(Suppl 2): 238-55. doi:http:// dx.doi.org/10.1590/1980-5497201500060021.

18. Malik VS, Willett WC, Hu FB. Global obesity: trends, risk factors and policy implications. Nat Rev Endocrinol. 2013 Jan; 9(1): 13-27. doi: http://dx.doi. org/10.1038/nrendo.2012.199.

19. Kim Y, Austin SB, Subramanian SV, Kawachi I. Body weight perception, disordered weight control behaviors, and depressive symptoms among Korean adults: The Korea National Health and Nutrition Examination Survey 2014. PLoS One. 2018 Jun 14; 13(6): e0198841. doi: http://dx.doi.org/10.1371/journal. pone. 0198841 .

20. Voelker DK, Reel JJ, Greenleaf C. Weight status and body image perceptions in adolescents: current perspectives. Adolesc Health Med Ther. 2015 Aug 25; 6: 149 58. doi: http://dx.doi.org/10.2147/AHMT.S68344.

21. Miranda VPN, Filgueiras JF, Neves CM, Teixeira PC, Ferreira MEC. Body dissatisfaction in college students of different study areas. J. Bras d Psiq. 2012 61(1): 25-32. doi: http://ddx.doi.org/10.1590/S0047-20852012000100006.

22. Sand AS, Furberg AS, Lian OS, Nielsen CS, Pettersen G, Winther A, et al Cross-sectional study of the differences between measured, perceived and desired body size and their relations with self-perceived health in young adults: The Troms $\varnothing$ Study - Fit Futures 2. Scand J Public Health. 2017 May; 45(3): 322
30. doi: http://dx.doi.org/10.1177/1403494817690941.

23. Pechey R, Monsivais P. Socioeconomic inequalities in the healthiness of food choices: Exploring the contributions of food expenditures. Prev Med. $2016 \mathrm{Jul}$; 88: 203-9. doi: http://dx.doi.org/10.1016/j.ypmed.2016.04.012.

24. Giskes K, Avendano M, Brug J, Kunst AE. A systematic review of studies on socioeconomic inequalities in dietary intakes associated with weight gain and overweight/obesity conducted among European adults. Obes Rev. 2010 Jun;11(6): 413-29. doi: http://dx.doi.org/10.1111/j.1467-789X.2009.00658.x.

25. Ghandour RM, Overpeck MD, Huang ZJ, Kogan MD, Scheidt PC. Headache, stomachache, backache, and morning fatigue among adolescent girls in the United States: associations with behavioral, sociodemographic, and environmental factors. Arch Pediatr Adolesc Med. 2004 Aug; 158(8): 797-803. PubMed PMID: 15289254.

26. Shackleton N, Jamal F, Viner R, Dickson K, Hinds K, Patton G, Bonell C. Systematic review of reviews of observational studies of school-level effects on sexual health, violence and substance use. Health Place. 2016 May; 39: 168-76. doi: http://dx.doi.org/10.1016/j.healthplace.2016.04.002.

27. Štefan L, Sporiš G, Krističević T. The associations between sleep duration and sleep quality with self-rated health in young adults: a population-based study. Int J Adolesc Med Health. 2018 Oct 20. pii:/j/ijamh.ahead-of-print/ ijamh-2018-0007/ijamh 2018-0007.xml. doi: http://dx.doi.org/10.1515/ ijamh-2018-0007

How to cite this article /Como citar este artigo:

Gomes CLR, Chaves-Júnior SC, Gavião MBD. Self-perceived health in dental students: a cross-sectional study. J Health Biol Sci. 2020 J; 8(1):1-8. 